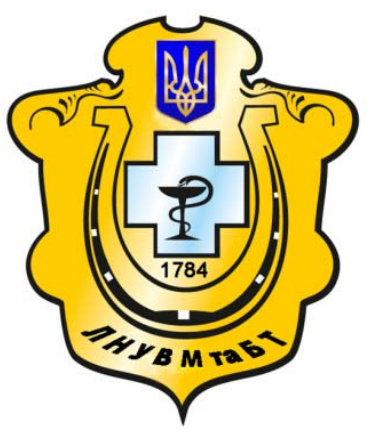

Науковий вісник Львівського національного університету ветеринарної медицини та біотехнологій імені С.3. Гжицького

Scientific Messenger of Lviv National University of Veterinary Medicine and Biotechnologies named after S.Z. Gzhytskyj

doi:10.15421/nvlvet7109

ISSN 2413-5550 print

ISSN 2518-1327 online

$\underline{\text { http://nvlvet.com.ua/ }}$

УДК 619: 614.9: 579

\title{
Якісні зміни молока-сировини за впливу різних гігієнічних умов отримання
}

\author{
Л.А. Кондрасій, О.М. Якубчак \\ 1.kondrasiy@nubip.edu.ua \\ Наџіональний університет біоресурсів і природокористування Украӥни, \\ вул. Героїв Оборони, 11, м. Київ, 03041, Украӥна
}

\begin{abstract}
У статті подано результати вивчення стабільності щуодо кількості МАФАнМ та соматичних клітин молока-сировині впродовж року, отриманого в умовах ферм різних областей України. Залежно від рівня виконання гігієнічних вимог отримання молока ферми були розділені на дві групи. Оиінку стабільності проводили за частотою перебування показників КМАФАнМ та кількості соматичних клітин молока в інтервалах сформованих відповідно до татунків начіонального стандарту. Виявлено, щэо молоко-сировина з ферм із належним виконанням гігієнічних вимог за показниками кількості МАФАнМ та соматичних клітин перебувала у одному та трьох інтервалів, відповідно. Згідно отриманих результатів висунуто рекомендаиії щодо можливості проведення періодичних досліджень молока-сировини зазначених ферм.

Частота значень показників кількості МАФАнМ та соматичних клітин молока-сировини з ферм, де виявлені невідповідності виконання гігієнічних вимог варіювала майже в 3-х та 2-х інтервалах відповідно, розділившись практично порівну за відсотковим співвідношенням. Значення частоти середньомісячного показника кількості соматичних клітин в молочі

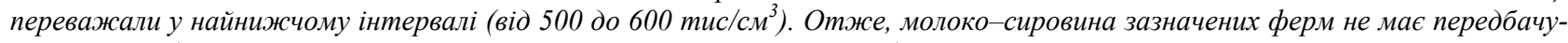
ваності впродовж року та вимагає частих перевірок за показниками безпечності та якості.

Ключові слова: молоко-сировина, КМАФАнМ, кількість соматичних клітин, гігієнічні вимоги отримання молока, інтервали, татунки.
\end{abstract}

\section{Качественные изменения молока-сырья под влиянием различных гигиенических условий получения}

\author{
Л.А. Кондрасий, О.М. Якубчак \\ 1.kondrasiy@nubip.edu.ua \\ Наииональный университет биоресурсов и природопользования Украины,, \\ ул. Героев Обороны, 11, Киев, 03041, Украина
}

В статье представлены результаты изучения стабильности количества мезофильних аэробних и факультативних анаэробних микроорганизмов и количества соматических клеток в молоке-сырье в течение года, полученного на фермах различных областей Украины. Фермы, где проводились исследования, были разделены на две группы в зависимости от уровня выполнения гигиенических требований получения молока. Оценку стабильности проводили по частоте выявления показателей количества МАФАнМ и соматических клеток в молоке в интервалах, сформированных в зависимости от сорта согласно действующего наџионального стандарта. Выявлено, что молоко-сырье из ферм с надлежашим выполнением гигиенических требований по показателям количества МАФАнМ и соматических клеток находилась в одном и трех интервалах, соответственно. Таким образом, для молока-сырья из указанных ферм можно рекомендовать периодические исследования указанных показателей.

Частота значений показателей количества МАФАнМ и соматических клеток молока-сырья из ферм, где обнаружены несоответствия выполнения гигиенических требований, варьировала в 3-х и 2-х интервалах, соответственно, разделившись примерно равно по прочентному соотношению. Значение частоты среднемесячного показателя количества сомати-

\section{Citation:}

Kondrasiy, L., Yakubchak, O. (2016). Study of quality parameters of raw milk stability by various dairy farming practices. Scientific Messenger LNUVMBT named after S.Z. Gzhytskyj, 18, 3(71), 41-44. 
ческих клеток в молоке преобладали в низком интервале (от 500 до 600 тыс/см ${ }^{3}$ ). Следовательно, молоко-сырье из указанных ферм не имеет предсказуемости в течение года и требует частых проверок по показателям безопасности и качества.

Ключевые слова: молоко-сырье, КМАФАнМ, количество соматических клеток, гигиенические требования получения молока, интерваль, сорт.

\title{
Study of quality parameters of raw milk stability by various dairy farming practices
}

\author{
L. Kondrasiy, O.Yakubchak \\ 1.kondrasiy@nubip.edu.ua \\ National University of life and environmental sciences of Ukraine, \\ Heroyiv Oborony Str., 11, Kyiv, 03041, Ukraine
}

\begin{abstract}
In Ukraine still remains relevant practice testing and purchase of raw milk by four quality classes. But for a long time in Ukraine working farms with modern methods zootechnical and veterinary management, with good dairy farming practices and good milking hygiene practices. So the aim of our study was to compare total bacteria count and somatic cells count in raw milk from this farms and farms that are still provided traditional (where were found some mistakes in milking hygiene practices) dairy farming practices in Ukraine. The quality parameters of raw milk were collected from farms located in Kiev, Cherkassy, Poltava, Chernihiv and Vinnitsa regions of Ukraine. Totally -17 farms in both groups. Research period - one year (2015/12-01). In the paper presented results of stability during the year of the quality parameters of raw milk received from farms of some regions of Ukraine. Farms which were taken for the study were divided into two groups, by various dairy farming practices. The stability evaluation was performed by intervals of determinations of total bacteria count rate and somatic cells count in milk. The intervals of determinations were defined according to Ukraine standard 3662-97. Established that total bacteria count and somatic cells count rate of raw milk from farms with good dairy farming practices was at one and three intervals, respectively. So, for these raw milk we can recommended periodic testing. The intervals of determinations of total bacteria count and somatic cells count of raw milk from farms, were found some mistakes in milking hygiene practices varied, at 3 and 2 intervals respectively and divided in equal parts by the percentage.

The value of the monthly average rate of somatic cells count in milk predominated in the largest range (from 500 to 600 $\times 1000 / \mathrm{mL}$ ). Consequently, raw milk, from this farm has no predictability throughout the year and requires frequent checks of safety and quality.
\end{abstract}

Key words: raw milk, dairy farming practices, total bacteria count, somatic cells count, intervals of determinations.

\section{Вступ}

Нині в Україні створені та активно працюють ферми, де застосовуються сучасні методи зоотехнічного та ветеринарного менеджменту. Отримання молокасировини відбувається 3 належним дотриманням вимог гігієни (Antonova, 2014; Jarmak, 2016). В той же час значна частка ферм працюють за традиційними в Україні практиками і виробляють молоко $з$ широким діапазоном вмісту кількості МАФАнМ та соматичних клітин, що підтверджують дослідження Я.Й. Крижанівського, Т.В.Полтавченко, М.Д. Кухтина, O.M. Якубчак (Kuhtyn, 2011; Jakubchak et al., 2012; Tančin, 2013).

Метою наших досліджень було визначити числові діапазони коливання впродовж року показників кількості МАФАнМ та соматичних клітин у молоцісировині з ферм із різними рівнями виконання гігієнічних вимог.

\section{Матеріал і методи досліджень}

Використано виробничі показники молокасировини з ферм Київської, Черкаської, Полтавської, Чернігівської та Вінницької областей України. Всього проаналізовані дані з 17 ферм. Проводили оцінку середньомісячних значень показників кількості мезофільних аеробних та факультативних анаеробних мікроорганізмів (КМАФАнМ) (згідно ДСТУ 3662-97 - загальне бактеріальне обсіменіння) та кількості соматичних клітин. Збір даних виконано за період 3 січня по грудень 2015 р. Статистична обробка даних проводилася 3 використанням статистичних функцій табличного процесора MS Excel стандартного пакету MS Office.

\section{Результати та їх обговорення}

Першочергово досліджувані ферми було розподілено дві групи. До I групи увійшли 7 ферм 3 належним виконанням гігієнічних вимог. На вказаних фермах були запроваджені спеціальні системи контролю гігієни виробництва молока, а саме, наявність доїльних залів та/або контролюється виконання належного очищення молокопроводів та догляду за вим'ям, та/або введено систему винагороди операторів машинного доїння за належні показники якості молокасировини тощо. Другу групу сформовано із 10 ферм, які працюють за традиційною в Україні практикою, тобто, де виявлені невідповідності щодо належного виконання гігієнічних вимог отримання молока. На фермах II групи були відсутні доїльні зали, доїння проводиться безпосередньо в стійлах та/або не введено систему винагороди операторів машинного доїння, та/або специфічної системи контролю очищення молокопроводів та догляду за вим'ям на фермі не передбачено тощо.

Значний відсоток залягання середньомісячних значень якісних показників молока в певному діапазоні може свідчити про передбачуваність діяльності 
ферми з отримання молока-сировини належної якості. Для інтерпретації зазначеної інформації дані середньомісячних показників кількості МАФАнМ та соматичних клітин досліджуваних груп ферм розподілено за інтервалом в 100 тис. КУО/ $\mathrm{cm}^{3}$ або тис./ $\mathrm{cm}^{3}$, що відповідає вимогам чинного ДСТУ і Регламенту ЄС
853/2004 від 29.04.2004 р. Результати залягання середньомісячних значень кількості МАФАнМ та соматичних клітин в молоці в певному інтервалі щодо кожної ферми, сума значень та відсоткові еквіваленти кожного інтервалу оформлено в табл. 1 та 2.

Таблиияя 1

Частота залягання за інтервалами середньомісячних значень кількості МАФАнМ та соматичних клітин в молоці-сировині з ферм із належним дотриманням вимог гігісни

\begin{tabular}{|c|c|c|c|c|c|c|c|c|c|}
\hline Інтервали & $\begin{array}{c}\text { ферма } \\
\text { №1 }\end{array}$ & $\begin{array}{c}\text { ферма } \\
\text { №2 }\end{array}$ & $\begin{array}{c}\text { ферма } \\
\text { №3 }\end{array}$ & $\begin{array}{c}\text { ферма } \\
\text { №4 }\end{array}$ & $\begin{array}{c}\text { ферма } \\
\text { №5 }\end{array}$ & $\begin{array}{c}\text { ферма } \\
\text { №6 }\end{array}$ & $\begin{array}{c}\text { ферма } \\
\text { №7 }\end{array}$ & $\Sigma$ & $\%$ \\
\hline \multicolumn{10}{|c|}{ Значення показника КМАФАнМ } \\
\hline$\leq 100$ & 12 & 12 & 12 & 12 & 12 & 12 & 12 & 84,0 & 100,0 \\
\hline \multicolumn{10}{|c|}{ Значення показника соматичних клітин } \\
\hline$\leq 100$ & - & - & - & - & - & - & - & - & - \\
\hline $\begin{array}{l}\text { від } 101 \\
\text { до } 200\end{array}$ & - & - & - & - & - & 7 & - & 7,0 & 8,3 \\
\hline $\begin{array}{l}\text { від } 201 \\
\text { до } 300\end{array}$ & 1 & 1 & - & 2 & - & 5 & 12 & 21,0 & 25,0 \\
\hline $\begin{array}{r}\text { від } 301 \\
\text { до } 400\end{array}$ & 11 & 11 & 9 & 10 & 12 & - & - & 53,0 & 63,1 \\
\hline $\begin{array}{r}\text { від } 401 \\
\text { до } 500\end{array}$ & - & - & 3 & - & - & - & - & 3,0 & 3,6 \\
\hline & & & & & & & & 84,0 & 100,0 \\
\hline
\end{tabular}

За результатами досліджень, наведеними в табл. 1 щодо ферм I групи, можна зробити висновок про передбачуваність виробництва молока-сировини належної якості за досліджуваними показниками впродовж року та стабільність у належному дотриманні санітарно-гігієнічних вимог і здоров'я тварин. Зазначені твердження сформовані у зв'язку із заляганням значень показника КМАФАнМ молокасировини всіх ферм I групи в інтервалі до 100 тис.
КУО/см³ . Крім того, відсоткова перевага значень показника кількості соматичних клітин в молоці знаходилися в двох інтервалах, а саме, $63,1 \%$ середньомісячних значень перебували в діапазоні від 301 до 400

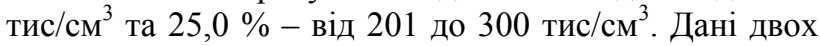
ферм вийшли за межі вказаного діапазону. Зокрема дані ферми № 3 та №6. Найнижчу кількість соматичних клітин на фермі № 6 пов’язуємо із запровадженням заходів вакцинопрофілактики маститу.

Таблиия 2

Частота залягання за інтервалами середньомісячних значень показників кількості МАФАнМ та соматичних клітин молока-сировини з ферм, де виявлені невідповідності виконання окремих гігіснічних вимог

\begin{tabular}{|c|c|c|c|c|c|c|c|c|c|c|c|c|}
\hline Інтервали & 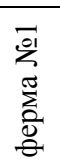 & 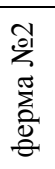 & 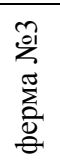 & 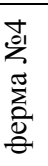 & 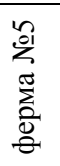 & 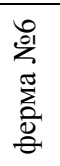 & 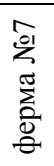 & 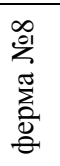 & 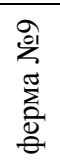 & 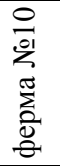 & $\Sigma$ & $\%$ \\
\hline \multicolumn{13}{|c|}{ Значення показника КМАФАнМ } \\
\hline$\leq 100$ & - & - & - & - & - & - & - & - & - & - & 0 & 0 \\
\hline $\begin{array}{l}\text { від } 101 \\
\text { до } 200\end{array}$ & - & - & - & - & - & - & - & - & 1 & - & 1,0 & 0,8 \\
\hline $\begin{array}{l}\text { від } 201 \\
\text { до } 300\end{array}$ & - & - & 2 & 1 & - & 1 & 5 & 4 & 9 & 4 & 26,0 & 21,7 \\
\hline $\begin{array}{l}\text { від } 301 \\
\text { до } 400\end{array}$ & 5 & 3 & 6 & 6 & 5 & 7 & 6 & 5 & 2 & 8 & 53,0 & 44,2 \\
\hline $\begin{array}{l}\text { від } 401 \\
\text { до } 500\end{array}$ & 7 & 9 & 4 & 5 & 7 & 4 & 1 & 3 & - & - & 40,0 & 33,3 \\
\hline & & & & & & & & & & & 120,0 & 100,0 \\
\hline \multicolumn{13}{|c|}{ Значення показника кількості соматичних клітин } \\
\hline$\leq 300$ & - & - & - & - & - & - & - & - & - & - & 0 & 0 \\
\hline $\begin{array}{l}\text { від } 301 \\
\text { до } 400\end{array}$ & - & - & 1 & 1 & 2 & - & 2 & - & - & - & 6,0 & 5,0 \\
\hline $\begin{array}{c}\text { від } 401 \\
\text { до } 500\end{array}$ & 1 & 9 & 2 & 2 & 2 & 3 & 1 & 1 & 1 & 2 & 24,0 & 20,0 \\
\hline $\begin{array}{l}\text { від } 501 \\
\text { до } 600\end{array}$ & 11 & 3 & 9 & 9 & 8 & 9 & 9 & 11 & 11 & 10 & 90,0 & 75,0 \\
\hline & & & & & & & & & & & 120,0 & 100,0 \\
\hline
\end{tabular}


Дані ферм, де виявлені невідповідності виконання окремих гігієнічних вимог отримання молока (табл. 2), зумовили формування висновків, протилежних фермам I групи. Зокрема частота варіювання значень показника КМАФАнМ молока-сировини впродовж дослідного року з ферм II групи згідно відсоткового розподілу залягала переважно в трьох інтервалах. При цьому розподіл значень частоти по кожній фермі був різний. Такі варіації слугують ознакою впливу на зазначений показник значної кількості факторів, зокрема, якості проведення санітарногігієнічних заходів. Подолати межу КМАФнМ в мо-

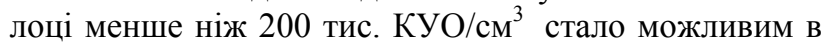
умовах ферми № 9, але лише в середньому значенні одного місяця дослідного року, що й утворило відсоток по групі - $0,8 \%$. Відсутність значимих закономірностей у виявленні частоти середньомісячних значень КМАФАнМ, дає підставу для висновку про необхідність проведення постійного контролю. Крім того, із інтервалу значень, що відхилялися від більш чисельно значимого (44,2\%), переважали (33,3\%) ті, які перебували в нижчому діапазоні - від 401 до 500 тис. КУО/см ${ }^{3}$. Із збільшенням КМАФАнМ підвищується ризик виявлення патогенних мікроорганізмів. Тому постійний контроль КАМАФАнМ у такому молоці слугує більше для підтвердження безпечності, ніж якості (Jakubchak et al., 2012).

Частота значень кількості соматичних клітин значимо була сконцентрована у двох інтервалах. Але, порівняно із даними I групи, діапазони цих інтервалів сягали від 501 до 600 тис/см ${ }^{3}$ для 75,0\% середньомісячних значень вказаного показника та від 401 до 500 тис $/ \mathrm{cm}^{3}$ - для $20,0 \%$. Пояснення залягання переважної частини середньомісячних значень кількості соматичних клітин у досить значному діапазоні вказує на недостатній рівень уваги до здоров'я корів/здоров'я вимені (зокрема неналежне дотримання правил гігієни доїння та догляду за вименем). Також можна висунути припущення про наявність хронічного маститу на фермах № 1, 8, 9 у зв'язку з тим, що частота значень впродовж року майже повністю сконцентрована у найнижчому інтервалі. Але така інформація може бути підтверджена окремо щодо кожної ферми і лише за умови досліджень індивідуальних проб молока впродовж певного періоду.

\section{Висновки}

Середньомісячні значення кількості МАФАнМ та соматичних клітин молока-сировини, отриманого на фермах I групи перебувала у одному та трьох інтервалах, відповідно. Тобто таке молоко має стабільну якість впродовж року. Частота значень показника КМАФАнМ та кількості соматичних клітин молокасировини ферм II групи варіювала в $3-\mathrm{x}$ та $2-\mathrm{x}$ інтервалах. Значення частоти середньомісячного показника кількості соматичних клітин в молоці переважали у найнижчому інтервалі (від 500 до 600 тис/см ${ }^{3}$ ). Тобто, молоко-сировина, отримана на фермах II групи не має передбачуваності впродовж року та вимагає постійного контролю за показниками безпечності та якості.

Перспективи подальших досліджень. Встановити можливість взаємозалежної зміни показників якості молока-сировини, встановлених для дослідження, під час закупівлі.

\section{Бібліографічні посилання}

Jarmak, A. (2016). «Zajve» moloko i znak jakosti. Moloko i ferma. 1(32), 8-11 (in Ukrainian).

Antonova, A. (2014). Tochne tvarynnyctvo na ukrai'ns'kyh molochnyh fermah. Moloko i ferma. 1(20), 51-53 (in Ukrainian).

Tančin, V. (2013). Somatic cell counts in milk of dairy cows under practical conditions Slovak. J. Anim. Sci. 46(1), 31-34.

Kuhtyn, M.D. (2011). Teoretychne obg'runtuvannja veterynarno-sanitarnyh normatyviv i rozroblennja systemy kontrolju vyrobnyctva moloka korov'jachogo nezbyranogo oholodzhenogo: avtoref. dys. d-ra. vet. nauk: 16.00.06. L'viv (in Ukrainian).

Jakubchak, O.M., Kobysh, A.I., Kryvushhenko, G.O. (2012). Jakist' moloka koriv $\mathrm{v}$ umo-vah sil's'kogospodars'kogo pidpryjemstva. Naukovi dopovidi NUBiP. 7(36) http://www.nbuv.gov.ua/ejournals/Nd/2012_7/12yom.pdf (in Ukrainian).

DSTU 3662-97 «Moloko korov'jache nezby-rane. Vymogy pry zakupivli» iz zminoju №1 (IPS №52007) Kyi'v, Derzhspozhyvstandart Ukrai'ny (in Ukrainian).

Стаття надійшла до редакиії 5.09.2016 